\title{
GAKTINĖS SĄVARŽOS IŠSISKYRIMAS GIMDANT
}

\author{
Kamilė Dumalakaitė', Gustė Burneikaitė', Lina Minkevičiūtė ${ }^{2}$ \\ ${ }^{1}$ Lietuvos sveikatos mokslu universitetas, Medicinos fakultetas, \\ ${ }^{2}$ Lietuvos sveikatos moksly universiteto ligonine Kauno klinikos, Reabilitacijos klinika
}

Raktažodžiai: gaktinès sąvaržos išsiskyrimas, gaktinė sąvarža, diastazè, gimdymo komplikacijos.

\section{Santrauka}

Gaktinès sąvaržos išsiskyrimas gimdant yra reta patologija, pasitaikanti nuo 1 iš 30,000 iki 1 iš 300 gimdančiuju ir diagnozuojama vienu iš radiologinių tyrimo metodu nustačius $>10 \mathrm{~mm}$ pločio tarpo išsiplètimą. Rizikos veiksniai gali būti daugiavaisis něštumas, gimdymo metu naudojamos chirurginès žnyplès ir daug kitų būklių. Nors diastazè gali būti asimptominè, dažniausiai moterys jaučia labai intensyvų skausmą, dubens nestabilumą, sunkumą lipti laiptais ir kitus požymius, trukdančius pasirūpinti savimi bei kūdikiu. Šią patologiją galima gydyti konservatyviai, pasitelkiant vaistus bei ortopedines priemones arba operaciniu būdu, tačiau pastarasis taikomas tik esant itin dideliam tarpo išsiplètimui ar gyvybei pavojingoms komplikacijoms. Šioje literatūros analizėje apžvelgiamas gaktinès sąvaržos išsiplètimo apibréžimas, etiologija ir patofiziologija, klinika, diagnostika bei gydymas.

\section{Ivadas}

Gaktinès sąvaržos išsiskyrimas, kitaip vadinamas gaktinès sąvaržos diastaze ir ịvykstantis ne dèl gaktikaulio ar kito dubens kaulo lūžio, yra reta, tačiau sunki gimdymo komplikacija. Nors sąvaržos praplatėjimas gimdant vagininiu būdu yra ịprastas, nuo 1 iš 300 iki 1 iš 30000 moterų patiria nefiziologini praplatejjimą daugiau nei $1 \mathrm{~cm}[1,2]$. Daugejjant modernių diagnostikos metodų, patologijos dažnis didèja ir, tikètina, didès toliau [12]. Kadangi gaktinès sąvaržos išsiskyrimas yra gan retas ir dažnai nediagnozuojamas, sunku tinkamai ịvertinti rizikos veiksnius ir tinkamiausius gydymo metodus. Ši komplikacija moterims sukelia labai didelị skausmą, negalèjimą pasirūpinti savimi bei kūdikiu dèl progresuojančio silpnumo [2].

Tyrimo tikslas - apibrèžti, kas yra gaktinès sąvaržos išsiplètimas, etiologija ir patofiziologija, kokia šios patologijos diagnostika ir gydymas.

\section{Tyrimo medžiaga ir metodai}

Literatūra šiai apžvalgai rinkta naudojant Pubmed duomenų bazę. Literatūros paieška buvo atliekama naudojant parinktus raktinius žodžius, išnagrinèta daugiau kaip 30 publikacijų, susijusių su gaktinès sąvaržos išsiplètimu gimdymo metu.

\section{Tyrimo rezultatai}

Etiologija ir patofiziologija. Gaktinès sąvaržos išsiskyrimas siejamas su hormonų pokyčiais trečiąji něštumo trimestrą. Gaktinè sąvarža yra nesinovijinis, kremzlinis sąnarys, jungiantis kairę ir dešinę viršutines gaktikaulio šakas. Normalus gaktinès sąvaržos tarpas, matomas rentgenologinių tyrimų vaizduose, vidutiniškai yra $4 \mathrm{~mm}$ pločio. Veikiant progesteronui ir relaksinui (placentos išskiriamiems hormonams), šis atstumas gali padidèti dar 3-4 mm dèl gaktinių bei sakroileinių raiščiu atsipalaidavimo ir išlikti po nëštumo - fiziologinè diastazé, būtina normaliam vagininiam gimdymui [3,4]. Atliktame tyrime, kuriame tirta gaktinès sąvaržos dinamika gimdant ir po gimdymo naudojant ultrasonografiją, praplatejjimas aptiktas 59-94 proc. pacienčių (atsižvelgiant ị tikslią matavimo vietą). Praplatėjimo skersmuo svyravo nuo 9 iki 139 proc. pirminio skersmens [13]. Retais atvejais, gimdant gaktinè sąvarža praplatejja $>10 \mathrm{~mm}$ ir yra vadinama patologine gaktinès sąvaržos diastaze, galinčia sukelti sunkių komplikacijų ar netgi būti grèsminga gyvybei; tokiose situacijose reikalingas konservatyvus arba operacinis gydymas. Dažnai, esant šiai situacijai, matomas ir užpakalinès dubens žiedo pusès vientisumo pažeidimas [1,2,5]. Literatūroje aprašomi ịvairūs rizikos veiksniai: pirmasis nèštumas, daugiavaisis nèštumas, gimdant naudojamos chirurginès žnyplès, dažni ir stiprūs sąrèmiai, epidūriné anestezija, siauras motinos dubuo, ankstesnès dubens traumos, osteomaliacija, chondromaliacija, McRobert's manevras, infekcijos [5,6]. Gaktinès sąvaržos išsiskyrimą retais atvejais gali sukelti su nèštumu nesusijusios priežastys: trauma, šlapimo pūslès ekstrofija, trapių kaulų sindromas, hipotiroidizmas ir kitos 
ligos bei sindromai [7].

Klinika. Gaktinès sąvaržos diastazė gali pasireikšti prieš, per, bet dažniausiai po gimdymo; simptomai gali vèluoti iki 48 valandų dèl epidurinio nuskausminimo gimdymo metu, vaistams maskuojant simptomus [8]. Neretai gimdymo metu gali būti girdimas pokštelèjimas sąvaržos išsiskyrimo momentu. Kiti ịprastiniai požymiai yra nesiliaujantis skausmas priekiniame dubenyje ir pilvo apačioje, su arba be skausmo sakroileinių sąnarių projekcijoje dèl galimo jų pažeidimo. Skausmas gali plisti ị klubų sąnarius bei kojas, pasireiškia šlubavimas. Pacientėms sunku atlikti aktyvų ir pasyvų tiesios kojos kèlimą, klubų atvedimą ir suvedimą, reikia pagalbos keičiant padètį lovoje, lipant laiptais. Sudètingas bet koks fizinis aktyvumas. Galimas šlapimo susilaikymas, dèl kurio gali prireikti Folley kateterio [1,2].

Kai kuriais atvejais gaktinès sąvaržos išsiskyrimas gali būti asimptominis. Nors moterų, kurioms ši liga nepasireiškia jokiais simptomais, skaičius nèra tiksliai žinomas, ịvairūs tyrimai parodè, kad asimptominių pacienčių simptomų pasireiškimo riziką po antrinès traumos ar per didelio krūvio [9].

Diagnostika. Fizinio ištyrimo metu matomas pacientès išsekimas dèl skausmo, skausmingumas palpuojant atitinkamuose taškuose ar bandant pajudinti dubens žiedą. Gali būti matoma minkštujų audinių edema, hematoma gaktoje ar tarpvieteje, palpuojant jaučiamas tarpas gaktinejje sąvaržoje $[2,14]$. Teigiamas Patriko (Faber) testas ir Trendelenburgo simptomas [5].

Normalus gaktinès sąvaržos tarpas šiek tiek kinta su amžiumi ir priklauso nuo tyrimo priemonès - kompiuteriné tomografija ar rentgenograma. 20 metų moterų normalus sąvaržos plotis yra apie $6 \mathrm{~mm}$ tiriant rentgenu, o 50 metų apie $3 \mathrm{~mm}$. Storesnis kremzlinis diskas teikia didesni dubens kaulų mobilumą ir taip padeda gimdant [7]. Kliniškai ịtarus gaktinès sąvaržos išsiskyrimą, galima atlikti ultragarsini tyrimą, tačiau kartu turètų būti atliekama ir standartinè rentgenograma. Rentgenogramoje, kuri yra pagrindinis tyrimo metodas, patologijos metu matomas nenormalaus dydžio tarpas tarp gaktikaulių, prasiskyrimas $>10 \mathrm{~mm}$, stebimas nestabilumas stovint flamingo pozoje. $>20 \mathrm{~mm}$ pločio tarpas dažniausiai rodo, jog įtraukti ir sakroileiniai sąnariai. Kompiuterineje tomogramoje su 3D rekonstrukcija galima geriau apžiūrèti sąnarius ar kitus kaulų lūžius, esant traumai. MRT indikuotinas esant $>40 \mathrm{~mm}$ dydžio išsiskyrimui rentgenogramoje ir parodo minkštujų audinių pažeidimą bei uždegimą [2,7].

Nors gaktinès sąvaržos klinika ir diagnostika yra gana tipiška ir aiški, tiriančiajam gydytojui reiketų apsvarstyti kitas galimas dubens, klubų, nugaros ir kojų skausmo priežastis. Tai gali būti lytinių lūpų plyšimas, veninè tromboembolija, muskuloskeletinis nugaros apačios skausmas, lumbosakralinè radikulopatija, gaktinè osteolizè, osteomielitas, navikai, abscesai ir kita [2]. Tam reikalinga išsami anamnezè, klinikinis ištyrimas, instrumentiniai tyrimai.

Gydymas. Nors gaktinès sąvaržos diastazès gydymo pasirinkimų yra daug, nuo konservatyvių iki operacinių, dèl patologijos retumo nèra pakankamai įrodymais pagrịstu duomenų, kuris iš šių gydymo būdų efektyviausias ir saugiausias [5]. Literatūroje aprašomos tokios taktikos, kaip gulimas režimas (ịprastai lateral decubitus pozoje), fizioterapija, dubens fiksacija, uždara redukcija su dubens fiksacija, išorinis fiksavimas su ar be sakroileinių varžtų, vidinis fiksavimas su plokštele ir varžtais [2]. Kiekviena pacientè turi būti gydoma labai individualiai. Po gimdymo padidèja komplikacijų rizika operacijų metu, o ilgai trunkantis išsekimas ir skausmas gali trukdyti rūpintis naujagimiu ir savimi, todèl kiekvieną kartą reikia išrinkti tinkamiausią gydymo metodą, atsižvelgiant ị galimas pasekmes.

Gaktinès sąvaržos išsiskyrimo laipsnis ir taikomas gydymas gali būti nustatomas pagal plotị: 1) išsiskyrimas 1-2,5 $\mathrm{cm}$ gydomas konservatyviai, 2) išsiskyrimas $2,5-4 \mathrm{~cm}$ siejamas su sakroileinių sąnarių pažaida ir operacinis gydymas gali būti svarstomas, 3 ) išsiskyrimas $>4 \mathrm{~cm}$ dažniausiai gydomas operaciniu būdu [1]. Renkantis gydymo taktiką, atsižvelgiama ị simptomų stiprumą. Esant asimptominei diastazei, iprastai gydymas netaikomas, nes tokie atvejai dažniausiai nèra išaiškinami; vis dèlto gali būti skiriamas gulimas režimas. Simptominis išsiskyrimas dažniausiai pasireiškia vidutiniškai sunkiais simptomais ir gydomas konservatyviai. Pagal poreiki vartojami analgetikai ar nesteroidiniai vaistai nuo uždegimo (NVNU) [5,7]. NVNU ir acetaminofenas yra pirmo pasirinkimo vaistai malšinti skausmą po gimdymo, jie tinkami tiek néščiosioms, tiek maitinančioms moterims. Dažniausiai gydymas pradedamas ibuprofenu, 400-600 mg doze keturis kartus per dieną; dozè gali būti koreguojama, atsižvelgiant ị situaciją [5]. Esant stipriam skausmui ir raumenų spazmams, gali būti skiriama juosmeninè epidurinè analgezija morfinu, bupivakainu ar fentaniliu [10]. Atlikti tyrimai ir nustatyta, jog galima naudoti intrasimfizialines steroidu injekcijas derinyje su vietiniais anestetikais, dažniausiai hidrokortizonu, chemotripsinu ir lidokainu [5]. Kartu su adekvačiu nuskausminimu skiriamos ir kitos konservatyvios gydymo priemonės, skirtos išlaikyti dubens žiedo stabilumą ir tinkamą funkciją. Naudojami dubens raiščiai, diržai ar petnešos, stabilizuojančios sakroileinius sąnarius bei tinkamai paskirstančios krūvị, tenkantị dubeniui, nugarai, klubams bei kojoms [5]. Vienas iš tokių ortopedinių prietaisų - elastiniai raiščiai, pagaminti iš neopreno, mažinantys dubens kaulų ir vidinių rotatorių raumenų judejjimą. Atlikus tyrimą, pastebèta, jog šie raiščiai vos per vieną dieną vidutiniškai sumažino gaktinès sąvaržos išsiskyrimą nuo 41 iki 12 
mm, o skausmą per 2 dienas nuo 10/10 iki 2/10 balų [16]. Pagerejimas naudojant konservatyvius gydymo metodus iprastai stebimas praejjus 6 savaitèms -6 mènesiams nuo simptomų pradžios.

Konservatyviai gydomos pacientès, turi būti stebimos bent vienerius metus. Jeigu praejus šiam laikotarpiui vis dar jaučiamas gaktinės sąvaržos ar sakroileinis skausmas, dubens nestabilumo simptomai, turi būti kartojama rentgenograma ar kompiuterinè tomografija. Radus degeneracinių pokyčių ar dubens nestabilumo požymių, indikuotinas operacinis gydymas. Nesant šių požymių, ieškoma kitų lètinio skausmo priežasčių [1].

Operacijos gaktinès sąvaržos išsiskyrimo atveju retai yra būtinos; indikacijos apima diastazę, kuri komplikavosi nervo kompresija, urogenitalinio trakto traumą, masyvu kraujavimą, neefektyvų konservatyvų gydymą, tarpo išsiplètimą $>4 \mathrm{~cm}$. Chirurginis gydymas, taikytas po neefektyvaus konservatyvaus gydymo, pasižymi didele pooperacinių komplikacijų rizika. Ankstyva operacija gali ne tik greičiau pagerinti bendrą savijautą bei sumažinti skausmą, bet ir išvengti dalinio sugijimo ar vẻlesnių sunkumų gydant [5]. Pagrindiniai operaciniai metodai yra priekinis tvirtinimas cirkliažine viela (anterior cerclage wiring), plokštelès ir išorinè fiksacija. Vidinis fiksavimas naudojant plokštelę sukelia mažiau komplikacijų, lyginant su tvirtinimu tik viela arba tik sraigtu, todèl šis metodas dažniausiai naudojamas kasdienėje praktikoje. Vis dèlto, fiksavimas plokštele gali sukelti tokių komplikacijų kaip infekcija, minkštujų audinių sudirginimas, negalëjimas pritvirtinti ir sraigtų atsipalaidavimas, pasikartojantis gaktinės sąvaržos išsiskyrimas [5,11]. Pastaruoju metu populiareja minimaliai invazyvios chirurgijos technikos, kadangi jos laikomos saugesnèmis komplikacijų atžvilgiu. Dẻl mažų pjūvių ženkliai mažèja infekcijos rizika, rečiau pasitaiko išvaržų, jaučiamas mažesnis pooperacinis skausmas, didesnis judrumas [5]. Atliekant minimaliai invazyvią operaciją modifikuotu PSRF metodu (angl. pedicle screw-rod fixation), prarandama mažiau kraujo, mažiau pažeidžiami minkštieji audiniai, trumpesnis operacijos laikas ir galimas ankstyvas krūvis [17].

Literatūroje aprašomas atvejis, kai 27 metų moteris, po $34+6$ savaičių nekomplikuoto néštumo pagimdè dvynius natūraliu vagininiu būdu. Iškart po gimdymo atsirado lytinių lūpų hematoma, o praèjus keletui valandų, moteriai išsivystė hemodinaminis nestabilumas. Atlikus rentgenogramą ir kompiuterinę tomogramą, aptiktas $4,7 \mathrm{~cm}$ gaktinès sąvaržos išsiskyrimas ir nedidelis arterijos įtrūkimas. Praejjus savaitei, diastazè padidejo iki $6 \mathrm{~cm}$. Pacientei atlikta operacija ir praejjus 21 dienai po gimdymo ji išleista namo. Tai vienas iš retų atvejų, kai gaktinès sąvaržos išsiskyrimas gali būti grèsmingas gyvybei ir gydomas operaciniu būdu [15].

\section{Rezultatų apibendrinimas}

Nors gaktinès sąvaržos išsiskyrimas gimdant apibūdinamas kaip reta patologija, tikrieji skaičiai nèra žinomi, kadangi dauguma gydytojų nesusimąsto apie ši sutrikimą o moterys simptomus, juntamus dèl diastazès, apibūdina kaip normalų ir ịprastinį skausmą po gimdymo. Toms, kurios vis dèlto kreipiasi ị gydytojus, diagnozè patvirtinama atlikus klinikinį tyrimą ir rentgenogramoje radus $>10 \mathrm{~mm}$ gaktinès sąvaržos tarpą. Pagal tai, kokio pločio yra tarpas ir pagal juntamų simptomų stiprumą, galima skirti konservatyvų gydymą NVNU bei įtvarais arba operacinį gydymą, fiksuojant gaktinę sąvaržą. Greitas ir veiksmingas pagerejjimas taikant konservatyvų gydymą įrodo, jog operacinis gydymas gaktinės sąvaržos išsiskyrimo atveju yra reikalingas tik išskirtiniais atvejais.

\section{Išvados}

1. Gaktinès sąvaržos praplatėjimas $>10 \mathrm{~mm}$ vadinamas patologine gaktinès sąvaržos diastaze, galinčia sukelti sunkių komplikacijų ar netgi pavojų gyvybei.

2. Gaktinès sąvaržos diastazę gali sukelti tiek su néštumu susiję hormoniniai pokyčiai, tiek su něštumu nesusijusios priežastys.

3. Kiekviena pacientè turi būti gydoma individualiai ir gydymo parinkimas priklauso nuo sąvaržos išsiskyrimo laipsnio.

\section{Literatūra}

1. Uvarovas V., Žukauskas P., Šiatkus T., Masionis P. Dubens sąvaržos diastazė po gimdymo: atvejo pristatymas ir literatūros apžvalga. Lietuvos chirurgija, 2015;14(2):105-10.

https://doi.org/10.15388/LietChirur.2015.2.8249

2. Seidman AJ, Siccardi MA. Postpartum pubic symphysis diastasis. StatPearls Publishing 2020.

3. Parry LJ, McGuane JT, Gehring HM, Kostic IGT, Siebel AL. Mechanisms of relaxin action in the reproductive tract: studies in the relaxin-deficient (Rlx-/-) mouse. Ann NY Acad Sci 2005;1041(1):91-103.

https://doi.org/10.1196/annals.1282.013

4. Hagen R. Pelvic girdle relaxation from an orthopaedic point of view. Acta Orthop Scand 1974;45(4):550-63.

https://doi.org/10.3109/17453677408989178

5. Norvilaite K, Kezeviciute M, Ramasauskaite D, Arlauskiene A, Bartkeviciene D, Uvarovas V. Postpartum pubic symphysis diastasis-conservative and surgical treatment methods, incidence of complications: two case reports and a review of the literature. World J Clin Cases 2020;8(1):110-9.

https://doi.org/10.12998/wjcc.v8.i1.110

6. Yoo JJ, Ha Y-C, Lee Y-K, Hong JS, Kang B-J, Koo K-H. Incidence and risk factors of symptomatic peripartum diastasis of pubic symphysis. J Korean Med Sci 2014;29(2):281-6. 
https://doi.org/10.3346/jkms.2014.29.2.281

7. Skandhan AKP. Pubic diastasis. Radiopaedia.org.

https://radiopaedia.org/articles/pubic-diastasis

8. Herren C, Sobottke R, Dadgar A, Ringe MJ, Graf M, Keller K, et al. Peripartum pubic symphysis separation--current strategies in diagnosis and therapy and presentation of two cases. Injury 2015;46(6):1074-80. https://doi.org/10.1016/j.injury.2015.02.030

9. Bombaci H. Outcome of internal fixation and corticocancellous grafting of symphysis pubis diastasis which developed after malunion of pubic Rami fracture. Hip Pelvis 2017;29(2):150-3. https://doi.org/10.5371/hp.2017.29.2.150

10. Scicluna JK, Alderson JD, Webster VJ, Whiting P. Epidural analgesia for acute symphysis pubis dysfunction in the second trimester. Int J Obstet Anesth 2004;13(1):50-2.

https://doi.org/10.1016/j.ijoa.2003.08.006

11. Park M-S, Yoon S-J, Choi S-M, Lee K. Is there a clinical benefit of additional tension band wiring in plate fixation of the symphysis? BMC Musculoskelet Disord 2017;18(1):40. https://doi.org/10.1186/s12891-017-1418-3

12. Chawla JJ, Arora D, Sandhu N, Jain M, Kumari A. Pubic symphysis diastasis: a case series and literature review. Oman Med J 2017;32(6):510-4.

https://doi.org/10.5001/omj.2017.97

13. Rustamova S, Predanic M, Sumersille M, Cohen WR. Changes in symphysis pubis width during labor. J Perinat Med 2009;37(4):370-3.

https://doi.org/10.1515/JPM.2009.051

14. Gräf C, Sellei RM, Schrading S, Bauerschlag DO. Treatment of parturition-induced rupture of pubic symphysis after spontaneous vaginal delivery. Case Rep Obstet Gynecol 2014;2014:485916. https://doi.org/10.1155/2014/485916

15. Buitendyk M, Brennan B, Vora P, Smith P, Winsor S. Acute intrapartum rupture of the pubic symphysis requiring resuscita- tion and surgical intervention: a case report. J Obstet Gynaecol Can 2018;40(1):68-71.

https://doi.org/10.1016/j.jogc.2017.05.028

16. Lasbleiz J, Sevestre F-X, Moquet P-Y. Using an elastic band device after a severe obstetric pubic symphyseal separation: clinical and imaging evaluation. Obstet Gynecol 2017;130(3):625-9. https://doi.org/10.1097/AOG.0000000000002194

17. Wang J, Cao L, Wu J, Wang Q, Bi C. Clinical and radiological short-term outcomes of pubic symphysis diastasis treated with modified pedicle screw-rod fixation. Eur J Trauma Emerg Surg 2020;46(4):865-71.

https://doi.org/10.1007/s00068-018-1050-4

\section{POSTPARTUM PUBIC SYMPHYSIS DIASTASIS: A LITERATURE REVIEW}

K. Dumalakaitė, G. Burneikaitė, L. Minkevičiūtė

Keywords: pubic symphysis diastasis, pubic symphysis, diastasis, labor complications.

Summary

Postpartum pubic symphysis diastasis is a rare pathology with an incidence rate from 1 in 300 to 1 in 30,000 laboring women. It is diagnosed by observing a $>10 \mathrm{~mm}$ widening of the cartilaginous joint with one of the imaging methods. Risk factors include twin pregnancies, use of surgical forceps during labor and a lot more. Even though the diastasis can be asymptomatic, women usually experience very intense pain, pelvic instability, difficulty climbing up the stairs and other symptoms that cause decreased ability to take care of herself and the baby. This pathology can be treated conservatively by using medication and orthopedic devices or surgically; surgical method is used only in rare occasions, when there is a really large widening or life-threatening complications. In this literature review we discuss the definition, etiology, pathophysiology, symptoms, detection and treatment of pubic symphysis diastasis.

Correspondence to: kamile.dumalakaite@gmail.com

Gauta 2021-05-09 